\title{
A PRELIMINARY STUDY OF AERIAL VOLUME TABLE CONSTRUCTION FOR LODGEPOLE PINE IN WEST-CENTRAL ALBERTA ${ }^{1}$
}

\author{
By PATRICK J. B. DUFFY ${ }^{2}$ and MERLE P. MEYER ${ }^{3}$
}

P. J. B. Duffy obtained his B.S.F. degree at The University of British Columbia in 1955 and his M.F. from Yale University in 1956. After serving at the Petawawa Forest Experiment Station, Chalk River, Ontario for a year he was appointed as Research Officer in studies of forest land productivity in Alberta. In 1959-1961 he engaged in graduate studies at the University of Minnesota and was awarded the Ph.D. degree in June, 1962.

$A$ member of The University of Minnesota School of Forestry faculty since 1952, M.P. Meyer obtained his B.S.F. and Ph.D. degrees at Minnesota and his M.F. at the University of California. He served with the U.S. Army Air Corps in the U.S. and in China from 1940-1946 and was employed for various periods after the war by the U.S. Forest Service in Montana and Utah and with the forestry consulting firm of Hammon, Jensen, and Wallen in California.

\section{ABSTRACT}

Some aspects of photo-measurement and aerial volume table construction for the pure lodgepole pine type are dealt with. Tables giving gross stand volume in cubic feet are shown with stand height as the independent variable. Crown closure was not significantly correlated with gross stand volume in this study; probably because only fully-stocked stands were surveyed.

The 70-plot sample was divided into three strata composed of distinct parent materials. The data from stands on one stratum, the lacustrine deposits which are mapped as the Caroline Silt Loam soil series, were developed into a regression equation which differed from the composite equation (for all parent materials).

This study indicated that trained photogrammetrists can consistently measure tree heights to 8-foot height classes with a uniformly small standard error. It also indicates that a larger sample may permit the development of different aerial volume tables for different parent materials or soil types.

\section{INTRODUCTION}

There is a need in Alberta for the development of a method which would permit trained interpreters to accurately estimate gross stand volumes of lodgepole pine by means of air photo measurements. This species forms extensive, pure, even-aged stands over a wide range of sites in the wake of fires and,

\footnotetext{
${ }^{1}$ Based on a portion of a research problem submitted in June of 1961 to the Graduate School of the University of Minnesota in partial fulfilment of the requirements for the degree of Doctor of Philosophy; authorized for publication on July 31, 1961 as Sci. Jour. Ser. Paper No. 4675 of the Univ. of Minn. Agr. Expt. Sta.

- Research Officer, Forest Research Branch, Department of Forestry, Calgary, Alberta.

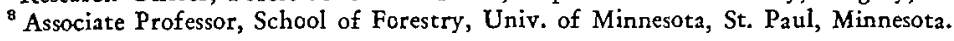


because of its uniformity, lends itself particularly well to photo measurement. The development of accurate aerial stand volume tables for this species could, conceivably, prove to be a useful tool in the collection of both management plan and research information.

However, the construction of an aerial stand volume table and determination of its applicability cannot be accomplished without the initial solution of various problems relating to it (e.g., interpreter training, relative accuracy of photo measurements possible, relationships of photo measurements to ground measurements). This study was initiated to explore problems of photointerpretation which are characteristic of lodgepole pine in west-central Alberta.

\section{Field Methods}

During the 1960 field season, in connection with a forest land productivity classification, 108 one-fifth acre plots were located in pure, even-aged well-stocked, 60-year-old lodgepole pine stands in the Foothills Section of west-central Alberta". At each plot a diameter tally was taken of all trees over 0.6" d.b.h. and the total basal area of the plot calculated and divided by the number of trees on the plot. From this the average diameter of the plot was computed as being equivalent to the diameter of the tree of average basal area. In addition, five trees of this average diameter were located on each plot and measured for total height. The mean of the five heights was used to enter a standard volume table for lodgepole pine (Blyth, $1955)$ to find the volume of the tree of average diameter. This value, when multiplied by the number of trees per acre, gave the total volume per acre for each one-fifth acre in cubic feet, including stump and top, bark excluded. It was this gross stand volume in cubic feet per acre which was used in the development of the prediction equations in this study.

\section{Photo InTERPRETATION}

Excellent quality infra-red minus-blue photography at a nominal scale of $1: 15,840$ was available for the project area ${ }^{5}$. This had been flown in 1957-58, hence one growing season intervened between time of photography and time of field measurement.

During March of 1961,70 of the original 108 field sample plots were arbitrarily selected and delineated on the photographs in their corresponding ground locations by means of a pin-prick. These photo plots were distributed over the three important parent materials in the study area as follows:

1. Stony glacial till, well-drained (Lobley Loam, Heavy Loam soil series) -23 plots.

2. Gravelly alluvium, excessively drained (Horburg Sandy Loam soil series)-21 plots.

3. Heavy lacustrine, poorly drained (Caroline Loam, Silt Loam soil series)-26 plots.

The photo measurements were made by three advanced forest photo-

\footnotetext{
- Rocky Mountain House and Brazeau Map Sheets.

- Photographs supplied through the courtesy of the Alberta Department of Lands and Forests, Forest Surveys Branch. Edmonton.
} 
grammetry students at the University of Minnesota, each of whom had had at least 60 hours of previous training in forest photo interpretation. Each interpreter made four parallax height measurements of average stand height with an Abrams Height Finder on a one-acre circle cut in frosted acetate paper and centered over the ground plot, and one estimate of crown closure on the same circle using Moessner's Central States Forest Experiment Station Crown Closure Scale. At no time were the interpreters known to have exchanged information with regard to their results.

\section{Data ANALYSIS}

The interpretation data were tabulated by interpreters and by plots and the mean readings of the three interpreters on each plot were calculated (i.e., mean stand height and crown closure). These plot data were then used to develop a multiple linear regression equation:

$$
\mathrm{Y}=-2710.07+130.51 \mathrm{X}_{1}+2.44 \mathrm{X}_{2}
$$

This equation had as its basis the following model (Snedecor, 1956): $\mathrm{Y}=\mathrm{a}+\mathrm{b}_{1} \mathrm{X}_{1}+\mathrm{b}_{2} \mathrm{X}_{2}$, where: $Y=$ gross stand volume per acre in cubic feet

$\mathrm{a}=$ the $\mathrm{Y}$ intercept

$b_{1}=$ regression coefficient for photo height $\left(X_{1}\right)$

$b_{3}=$ regression coefficient for photo crown closure $\left(\mathrm{X}_{2}\right)$

The equation was found to be significant at the $1 \%$ level and to have a standard error of estimate of $\pm 17.17 \%$. Because of the small size of the crown closure regression coefficient, however, there was serious question as to its importance. This suspicion was verified when a test revealed the $b_{a}$ to be non-significant, and it was discarded. Apparently, for the population measured, there was a significant linear relationship between photo height measurements and ground volume, but no significant relationship between crown closure estimates and ground volume. This is not surprising in view of the fact that the field plots had been selected with the purpose of obtaining growth data under conditions of full stocking. As a consequence, the plots obtained were generally of high crown closure levels, whereas the heights exhibited considerable range.

Calculation of the linear regression without the crown closure estimates resulted in the following prediction equation:

$$
\mathrm{Y}=-24.98+67.67 \mathrm{X}
$$

A plot of volume over photo height for the 70 plots indicated the relationship to be truly linear. Although a " $t$ " test of this equation indicated signficance at the $1 \%$ level, it must be remembered that the sample used was not selected at random and statements of confidence limits are, at best, only approximations. The local aerial stand volume table resulting from this equation is presented in Table 1.

In order to determine whether or not a significant relationship existed between the ground and photo measurements and the three parent materials, linear regressions were prepared for these three groups of plots. The equations for till and alluvium were found to be non-significant, but the equation for lacustrine sites was found to be significant at the $5 \%$ level:

$$
Y=-73.89+17.93 X_{1}+26.47 X_{2}
$$


TABLE 1.

Preliminary local Aerial Stand Volume Table for Fully-Stocked Lodgepole Pine Stands in West-Central Alberta (All Sites) ${ }^{1}$

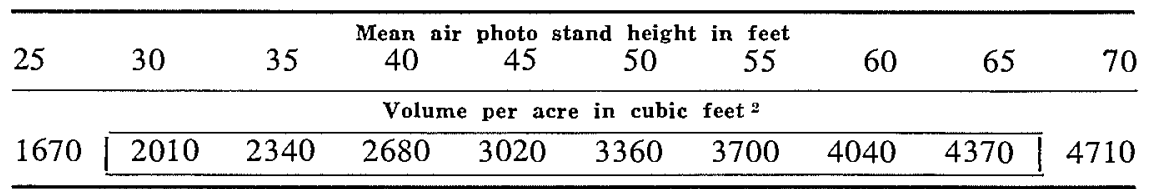

${ }^{2}$ Based on 70 one-acre plots on the Rocky Mountain House and Brazeau Map Sheet areas.

"Gross stand volumes are for all trees over $0.6^{\prime \prime}$ d.b.h., stump and top included; bark excluded. Block Lines indicate limits of basic data.

TABLE 2

Preliminary local Aerial Stand Volume Table for Fully-Stocked Lodgepole Pine Stands in West-Central Alberta (Lacustrine Sites) ${ }^{1}$

\begin{tabular}{|c|c|c|c|c|c|c|c|}
\hline 25 & 30 & 35 & $\begin{array}{ccc}\text { Mean air } & \text { photo stand height } \\
40 & 45 & 50\end{array}$ & $\begin{array}{l}\text { in feet } \\
55\end{array}$ & 60 & 65 & 70 \\
\hline & & & Volume per acre in cubic & feet $^{2}$ & & & \\
\hline 1550 & 1850 & 2160 & $\begin{array}{lll}2470 & 2780 & 3080\end{array}$ & 3390 & 3700 & 4010 & 4320 \\
\hline
\end{tabular}

${ }^{1}$ Based on 26 one-acre plots on the Rocky Mountain House and Brazeau Map Sheet areas.

"Gross stand volumes are for all trees over 0.6 " d.b.h., stump and top included; bark excluded. Block Lines indicate limits of basic data.

As in the composite prediction equation for all sites, testing revealed the $b_{a}$ to be non-significant. Recalculation of the linear regression without the crown closure estimates resulted in the following equation (significance at the $1 \%$ level was indicated by a " $t$ " test):

$$
\mathrm{Y}=6.14+61.56 \mathrm{X}
$$

The resulting local aerial stand volume table for lacustrine sites is presented in Table 2. It is considered to be of value only from the standpoint of comparison with the volume table for all sites, since it is felt that at least 50 plots would be required to produce a reliable table.

Probably the major importance of this study is the determination of an approximate range of accuracy of measurement and estimation which the trained interpreter can be expected to produce. Table 3 presents a comparative summary of ground measurements and mean photo measurements obtained by the interpreters. Not only are the standard errors of the photo estimates uniformly small, but also the mean photo height measurements compare very closely with those taken on the ground and reflect the general differences in stand height associated with the different sites involved. Crown closure estimates appear to be quite uniform for all sites, although it cannot be said categorically that they have no relationship to volume without verification from additional field and photo plots.

\section{Summary and Conclusions}

On the basis of the aerial photo measurements and crown density estimates 
TABLE 3

Summary Giving Photo Interpretation Results and Ground Measurements

\begin{tabular}{|c|c|c|c|c|c|c|c|c|c|c|}
\hline \multirow{2}{*}{$\begin{array}{c}\text { Sito } \\
\text { (parent } \\
\text { material) }\end{array}$} & \multirow{2}{*}{$\begin{array}{c}\text { No. } \\
\text { of } \\
\text { plots }\end{array}$} & \multirow{2}{*}{$\begin{array}{l}\text { Photo } \\
\text { inter- } \\
\text { preter }\end{array}$} & & \multicolumn{2}{|c|}{ Height measurements } & and & \multicolumn{2}{|c|}{$\begin{array}{l}\text { Crown density } \\
\text { estimate }\end{array}$} & \multicolumn{2}{|c|}{$\begin{array}{l}\text { Ground } \\
\text { volume }\end{array}$} \\
\hline & & & Mean & Std. error & Mean & Std. error & Mean & Std. error & Mean & Std. error \\
\hline \multirow{7}{*}{ Till } & \multirow{6}{*}{23} & & \multicolumn{2}{|c|}{ (feet) } & \multicolumn{2}{|c|}{ (feet) } & \multicolumn{2}{|c|}{ (per cent) } & \multirow{2}{*}{\multicolumn{2}{|c|}{ (cu. ft./acre) }} \\
\hline & & A & 47.6 & \pm 1.54 & \multirow{4}{*}{55.0} & \multirow{4}{*}{ \pm 1.30} & 83 & \pm 2.28 & & \\
\hline & & B & 57.0 & \pm 1.87 & & & 83 & \pm 2.57 & \multirow{3}{*}{3644} & \multirow{3}{*}{ \pm 166} \\
\hline & & C & 46.2 & \pm 1.42 & & & 77 & \pm 1.74 & & \\
\hline & & $\overline{\text { All }}$ & $\overline{50.0}$ & \pm 1.16 & & & $\overline{81}$ & $\overline{ \pm 1.92}$ & & \\
\hline & & A & 39.6 & \pm 2.00 & \multirow{4}{*}{41.8} & \multirow{4}{*}{ \pm 0.74} & 88 & \pm 2.62 & \multirow{4}{*}{2660} & \multirow{4}{*}{ \pm 114} \\
\hline & \multirow{3}{*}{21} & B & 41.0 & \pm 1.41 & & & 84 & \pm 2.66 & & \\
\hline \multirow[t]{2}{*}{ Alluvium } & & $\mathrm{C}$ & 38.0 & \pm 0.83 & & & 77 & \pm 3.28 & & \\
\hline & & $\overline{\text { All }}$ & 39.5 & \pm 0.84 & & & 83 & \pm 2.53 & & \\
\hline \multirow{4}{*}{ Lacustrine } & \multirow{4}{*}{26} & A & 48.3 & \pm 1.53 & \multirow{4}{*}{49.4} & \multirow{4}{*}{ \pm 0.74} & 84 & \pm 2.10 & \multirow{4}{*}{2923} & \multirow{4}{*}{ \pm 124} \\
\hline & & $\mathrm{B}$ & 49.7 & \pm 0.84 & & & 81 & \pm 2.18 & & \\
\hline & & $\mathrm{C}$ & 44.0 & \pm 1.18 & & & 79 & \pm 2.25 & & \\
\hline & & $\overline{\text { All }}$ & $\overrightarrow{47.4}$ & \pm 0.96 & & & $\overline{81}$ & $\overline{ \pm 1.98}$ & & \\
\hline \multirow{4}{*}{ All sites } & \multirow{4}{*}{70} & $\mathbf{A}$ & 45.4 & \pm 1.05 & \multirow{4}{*}{49.0} & \multirow{4}{*}{ \pm 0.84} & 85 & \pm 1.33 & & \\
\hline & & B & 49.5 & \pm 1.09 & & & 82 & \pm 1.39 & & \\
\hline & & $\mathrm{C}$ & 42.9 & \pm 0.78 & & & 78 & \pm 1.39 & 3081 & \pm 29 \\
\hline & & $\overline{\text { All }}$ & $\overline{45.9}$ & \pm 0.51 & & & $\overline{82}$ & $\overline{ \pm 1.20}$ & & \\
\hline
\end{tabular}


obtained by three interpreters from 70 one-fifth acre plots in fully-stocked west-central Alberta lodgepole pine stands, a volume prediction equation was developed:

$$
\begin{aligned}
& \mathrm{Y}=-24.98+67.67 \mathrm{X}, \\
& \text { where: } \mathrm{Y}=\text { gross volume per acre in cubic feet } \\
& \mathrm{X}=\text { mean photo stand height }
\end{aligned}
$$

These 70 plots were approximately equally distributed over three different parent materials: till, alluvium and lacustrine. Regression equations for the till and alluvium were not significant, but the lacustrine site volume prediction equation was significant and of the following form:

$$
\begin{aligned}
\mathrm{Y}=6.14 & +61.56 \mathrm{X}, \\
\text { where: } \mathrm{Y} & =\text { gross volume per acre in cubic feet } \\
\mathrm{X} & =\text { mean photo stand height }
\end{aligned}
$$

In no case was crown closure found to be significantly correlated with ground volume. Mean stand height measurements, however, were highly significantly correlated with ground volume measurements and were comparatively accurate and consistent between interpreters. On the basis of this test, it appears that similarly-trained interpreters using high quality photos can be expected to classify these stands into at least eight-foot height classes - possibly into five-foot classes. Crown closure estimates could not, of course, be equated in terms of any objective ground measurement, but were found to be quite consistent between interpreters.

One can only speculate as to whether the lack of correlation between photo density and ground volume found in this study is truly representative of average photo interpretation results to be expected for the area, or whether it is a function of the particular data collected (i.e., fully-stocked stands of one age class). It is interesting, therefore, to compare these two Alberta equations with those of Allison and Breadon (1958) for lodgepole pine and associated deciduous species (all ages) for two adjacent regions in British Columbia:

$$
\begin{aligned}
& \mathrm{V}=-113.469+3.328 \mathrm{H}-0.096 \mathrm{D} \text { (Central British Columbia) } \\
& \mathrm{V}=-90.400+2.846 \mathrm{H}+0.116 \mathrm{D} \text { (Southeast British Columbia) } \\
& \text { where: } \mathrm{V}=\text { gross vol./acre, 10's cubic feet, } 11.1^{\prime \prime}+\mathrm{d} . \mathrm{b} . \mathrm{h} \text {. } \\
& \mathrm{H}=\text { photo stand height } \\
& \mathrm{D}=\text { photo crown closure }
\end{aligned}
$$

The small size of the crown closure regression coefficients will be noted and, in fact, these are indicated by Allison and Breadon as being of questionable value. The two studies appear to support each other in this respect, although it must be pointed out that the Alberta equations are based on far fewer field plots and are correspondingly less reliable than those for British Columbia.

Inspection will reveal that the Alberta equations produce a considerably higher gross volume per acre estimate, which may be due to several causes: (1) the Alberta tables include all trees $0.6^{\prime \prime}+$ d.b.h., whereas the British Columbia tables include only trees $11.1^{\prime \prime}+$ d.b.h.; (2) regional differences in the species and in stand composition; and (3) the fact that the Alberta tables were based only on fully-stocked stands of one age. 
Some interesting possibilities with regard to the construction of reliable aerial stand volume tables for Alberta lodgepole pine are suggested by this study. Their exploration would, however, require an additional $30-50$ plots on each of the three sites in order to provide a representative cross-section of the stand variables present. As a result of these additional data, significant differences in the volume prediction equations might be found for individual sites or combinations thereof. The use of such aerial stand volume tables in conjunction with area soils maps could become a forestry tool with considerable practical importance. If there are no differences attributable to site, a simpler and equally valuable composite table could be developed for all sites.

\section{BibLIOGRAPHY}

ALLISON, G. W. and BREADON, R. E. 1958. Provisional aerial photo stand volume tables for interior British Columbia. Forestry Chron. 34: 77-83.

BLYTH, A. W. 1955. Standard volume tables for lodgepole pine in Alberta. Canada, Dept. Northern Affairs and National Resources, Forestry Branch, For. Res. Div., Tech. Note No.9. SNEDECOR, G. W. 1956. Statistical methods. Iowa State Coll. Press, Ames. 5th ed., pp. 414-415. 